\section{Ebola eradication may need wider partnership}

We are glad to hear that the World Health Organization (WHO) has conducted an emergency meeting to establish new control centres to contain the spread of Ebola in West Africa. ${ }^{1}$ It's well known that the sporadic Ebola outbreak started with the first human fatality in $1976 .^{2}$ Since then, outbreaks have come and gone sporadically within Africa. An experimental drug saved two lives recently, but more needs to be done to tackle the pandemic in Africa. Hence, we are compelled to ask the following questions: Why did the pharmaceutical industry and foreign-aid agencies ignore this disease for decades? Why do they worry now? Is it because infected patients are increasingly spreading across the globe? How many natural reservoirs does this virus have in Africa? A look at Ebola's history may shed some light on our current reality.

When one of us (G.A.) was doing surveys of monkeys and apes in the rainforests of Liberia during the late 1980s, there was no sign of Ebola. ${ }^{3}$ But deforestation had already begun, and chainsaws were closing in on national parks in Liberia, Sierra Leone and Ivory Coast. ${ }^{3}$ During the mid1990 s, there were reports of dying chimpanzees in Taï National Park, Ivory Coast. Later, laboratory tests confirmed that the culprit was the Ebola virus. ${ }^{4}$ The rate of deforestation has increased rapidly since the 1980s, coinciding with the increasing occurrence and frequency of deaths attributed to Ebola. The United Nations Environment Programme (UNEP) has warned that Sierra Leone's forests could disappear by $2018 .{ }^{5}$ Scientists must find find out whether or not deforestation aggravates Ebola outbreaks and where Ebola hides.

Although scientists have identified bats and apes as culprit carriers ${ }^{6}$ and victims $^{4}$ of the deadly disease, data are needed to pinpoint the source. Ongoing research will become more efficient if biodiversity scientists join hands with biomedical scientists to fill the grass- roots gap around the origin, ecology and behaviour of this virus.

Scientists have also speculated that the virus might have spread to humans through the consumption of bushmeat, ${ }^{7}$ and also through funeral rites where dead bodies are touched, washed and handled. These culturally sensitive issues cannot be dealt with easily. Social workers must join doctors to bring timely awareness.

In the name of biodiversity conservation, millions of dollars are spent each year in Africa, and biologists continue to collect animal samples for research. It's time for these biologists to team up with medical scientists and screen as many animals as possible to find the natural reservoirs of the Ebola virus and other viruses with the potential to affect humans. If health, social, biomedical and biodiversity experts combine their professional expertise, tackling the virus will become less frustrating. Governments, aid agencies and pharmaceutical firms must direct more funds toward solving the mysteries of this viral outbreak. The only way out of this crisis is to implement a wider partnership and fight this virus on all fronts.

\section{Govindasamy Agoramoorthy PhD, \\ Chiranjib Chakraborty PhD}

College of Pharmacy and Health Care (Agoramoorthy), Tajen University, Yanpu, Pingtung, Taiwan; Department of Bioinformatics (Chakraborty), Galgotias University, Greater Noida, India

\section{References}

1. Green A. Ebola emergency meeting established new control centers. Lancet 2014;384:118.

2. Pourrut X, Kumulungui B, Wittmann T, et al. The natural history of Ebola virus in Africa. Microbes Infect 2005; 7:1005-14.

3. Agoramoorthy G. Wildlife issues and crisis in a changing world: A naturalist's 25 years jungle journey in Asia, Africa and South America. Delhi (India): Daya Publishing House; 2009.

4. Formenty P, Boesch C, Wyers M, et al. Ebola virus outbreak among wild chimpanzees living in a rain forest of Cote d'Ivoire. J Infect Dis 1999;179: S120-6.

5. Sierra Leone: environment, conflict and peacebuilding assessment. Geneva: United Nations Environment Programme; 2010. Available: http:// postconflict.unep.ch/publications/Sierra_Leone.pdf

6. Leroy EM, Epelboin A, Mondonge V, et al. Human Ebola outbreak resulting from direct exposure to fruit bats in Luebo, Democratic Republic of Congo, 2007. Vector Borne Zoonotic Dis 2009;9: 723-8.

7. Wolfe ND, Daszak P, Kilpatrick AM, et al. Bushmeat hunting, deforestation, and prediction of zoonoses emergence. Emerg Infect Dis 2005;11:1822-7.

CMAJ 2014. DOI:10.1503/cmaj.114-0074

\section{Canadian Clinical Trials Coordinating Centre}

Thank you for covering the Canadian Clinical Trials Coordinating Centre (CCTCC) in your May 26, 2014, news article. ${ }^{1}$ We appreciate your interest in the CCTCC, however, the article is missing important information which we would like to share.

First, contrary to the headline, the CCTCC is a collaboration among three parties representing health care organizations (HealthCareCAN), pharmaceutical companies (Canada's Research-Based Pharmaceutical Companies) and government (Canadian Institutes of Health Reseach). The country's research hospitals, academic regional health authorities and their research institutes - represented through HealthCareCAN - are an equal party in this initiative and will offer significant in-kind contribution to help achieve the CCTCC's goals.

Second, safeguards are in place to protect against undue actual or perceived influence. This includes a carefully designed governance and decision-making model, a national advisory, expert working groups and a first-year evaluation.

Third, the recommendations in the action plan ${ }^{2}$ being implemented by the CCTCC are a starting point focused on how we expedite clinical trials in a safe, ethical, efficient and effective manner.

Clinical trials connect the promise of science to possibilities for patients. They are associated with innovative care for individuals, better clinical outcomes for participating organizations and ultimately, the human, social and economic benefits of health and prosperity for all. We are pleased to be part of this Canadian collaboration.

\section{Bill Tholl MA}

President and CEO, HealthCareCAN, Ottawa, Ont.

\section{References}

1. Vogel L. Feds and industry to overhaul clinical trials. CMAJ 2014;186:E345-6.

2. An action plan to help attract more clinical trials to Canada. Ottawa: Canada's Research-Based Pharmaceutical Companies, Canadian Institutes for Health Research, Association of Canadian Academic Healthcare Organizations; 2012. 